Anna E. Wolnowska

Maritime University of Szczecin

e-mail: a.wolnowska@am.szczecin.pl

Lech Kasyk

Maritime University of Szczecin

e-mail: 1.kasyk@am.szczecin.pl

\title{
STUDY ON THE DEVELOPMENT OF TRANSVERSAL COMPETENCES OF STUDENTS OF LOGISTIC
}

\begin{abstract}
Background: In the dynamically developing enterprises of the TFL industry, the demand for educated and competent employees is still growing. The educational process at the academic level should not only broaden the level of knowledge in this field but should also promote the development of transversal skills, such as entrepreneurship, communicativeness, creativity, and cooperation in the group.

The article aims to examine the effectiveness of using three selected heuristic methods to develop transversal skills in the field of Logistics at the Maritime University of Szczecin. The research also pertains to the pace of growth of these competences during the implementation of educational processes using the indicated methods.

Method: The method of accelerating the development of transversal competences in the process of students' practical education was used to test models of cross-functional skills development processes. The competence growth assessment was carried out in three stages, with the use of brainstorming, meta-plan and psychodrama. The competence level test was taken into account before the evaluation of the learning process models and after their completion. Nonparametric tests of multiple comparisons were used to analyze the results obtained. A matrix for the dependence increase in the applied case was based on the applied heuristic method.
\end{abstract}

Wolnowska A.E., Kasyk L.., Study on the Development of Transversal Competences of Students of Logistic [in:] Adamczak M. et al., Digitalization of Supply Chains, Spatium, Radom 2019, p. 160-176. https://doi.org/10.17270/B.M.978-83-66017-86-3.12 
Results: The considerations are illustrated by the results of calculations regarding the development of transversal competences of students, as well as the effectiveness of using selected heuristic methods used to raise them.

Conclusions: It was pointed out that after applying the proposed methods to students, the level of examined competences in most cases increased. The level of students' awareness of the knowledge of their transversal competences has also increased. Despite the complexity of the research, the method applied proved to be useful in studying the change in the level of transversal skills of students. There were no significant differences between the methods used and the rate of increase in competences depending on the specialty. Women, in most cases, develop their transversal skills better than men regardless of the mode of study.

Keywords: transversal competences, higher education, brainstorming, meta plan, psychodrama

\section{INTRODUCTION}

In knowledge-based economies the researchers working in particular fields emphasize the role and significance of transversal competences more and more [Amstrong 2005, Goliński et al. 2017] as opposed to core competences [Sutherland and Canwell 2007]. They help in selfrealization, personal and professional development, achievement of social integration and proper citizen's attitude. These skills are commonly referred to as general or interdisciplinary ones and constitute the amalgamation of knowledge, skills and attitudes necessary for the attainment of social goals [2006/962/EC].

Entrepreneurship [Zioło and Rachwał 2019, Błaszczyk 2019], creativity [eur-lex.europa.eu], teamwork and communicativeness stimulate the decision-making and risk management processes. They influence building of strategies not only in economic but also social systems [Sawyer 2006].

The labor market expects from academic institutions that their graduates should excel in entrepreneurship, creativity in problem solving and communication in teams [Szaniawska and Wolnowska 2015]. The examination of transversal skills and the determination of methods which could improve them are crucial for all the involved people: students, graduates, entrepreneurs and institutions [Srikanthan and Dalrymple 2004].

Wolnowska A.E., Kasyk L.., Study on the Development of Transversal Competences of Students of Logistic [in:] Adamczak M. et al., Digitalization of Supply Chains, Spatium, Radom 2019, p. 160-176.

https://doi.org/10.17270/B.M.978-83-66017-86-3.12 
The aim of the article is to examine the effectiveness of three selected heuristic methods for the development of transversal skills in the study specialization „Logistics” on the Maritime University in Szczecin. The research concerns also the rate of rise observed in terms of the above competences during the realization of education processes based on the use of these methods.

\section{RESEARCH METHODOLOGY}

The main tool used herein for the testing of transversal skill development process models was the „Method for accelerating the development of transversal skills in the practical students' education process", which, in the opinion of the scientists from Poznan University of Technology, facilitates the quicker acquisition of transversal competences such as entrepreneurship, creativity, teamwork and communicativeness [Graczyk-Kucharska et al. 2018, Szafrański et al. 2017, Spychała et al. 2017].

The method is a result of the works carried out within the project financed as part of Erasmus+ Program, and has been developed by a Polish-Finnish-Slovakian-Slovenian team for the purposes of educating the students (future employees), but it may also be applied for the education of students and within continued (post-graduate) education [Graczyk-Kucharska et al.2019a, Graczyk-Kucharska et al.2019b].

The estimation of competence rise has been carried out in three stages, using the methods of brainstorming, metaplan and psychodrama, while taking into account the results of the competence level tests carried out before the commencement of education process and afterwards. The process is presented graphically in Figure.1.

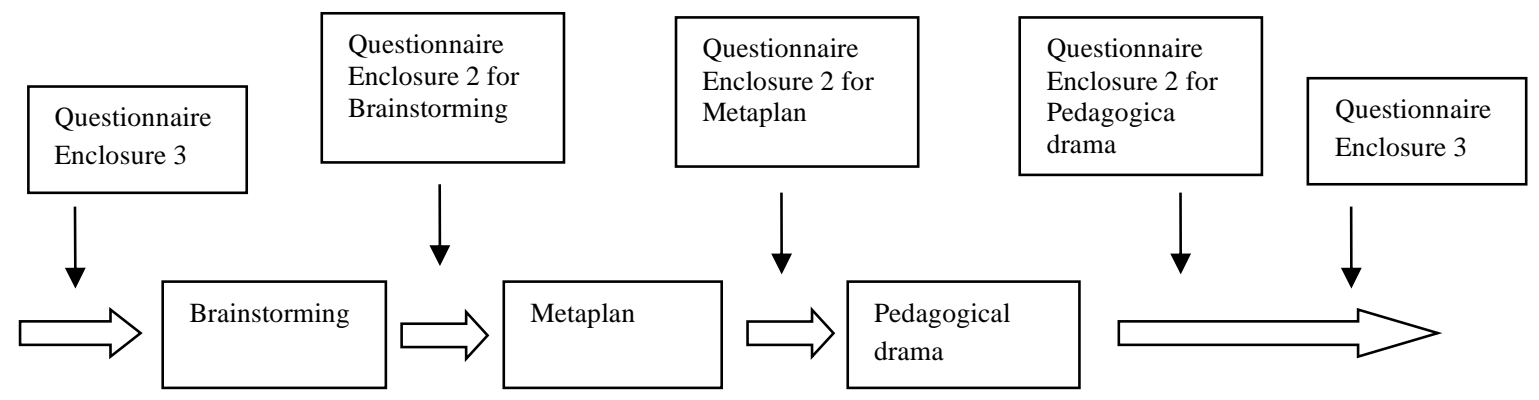

Fig.1. Phases of the application and evaluation of methods used for practical education in the process under design. Source: own elaboration based on the [Graczyk-Kucharska et al. 2019a].

Wolnowska A.E., Kasyk L.., Study on the Development of Transversal Competences of Students of Logistic [in:] Adamczak M. et al., Digitalization of Supply Chains, Spatium, Radom 2019, p. 160-176.

https://doi.org/10.17270/B.M.978-83-66017-86-3.12 
Two questionnaires have been used for the execution of the research, included in:

- Enclosure no.3, used at the beginning and in the end of research - The questionnaire for the assessment of students' transversal skill levels during practical education, which includes questions regarding entrepreneurship (6), creativity (3), teamwork (7) and communication (8). The level of each skill was assessed by the tested subjects using a sixsteps scale from 0 (no skill) to 5 (skill mastered in a very high degree).

- Enclosure no.2, used after the course based on each one of the three methods - The questionnaire for the assessment of improvement in the students' transversal skills, which includes indices regarding entrepreneurship (7), creativity (4), teamwork (8) and communication (9). The improvement in scope of each skill was assessed using a sixsteps scale from 0 (no improvement in the skill) to 5 (skill improved in a very high degree).

Brainstorming is a method frequently used for the solving of various problems, from simple to more complex ones, in the field the economics, production and social sciences. It has been developed in 1938 by A.F. Osborne who proposed some specific rules for its use, including the number of session participants ranging from 6 to 12 (same men as women). The team should include people directly involved in the problem as well as such persons who are going to stimulate the works of the group.

Brainstorming is a method which requires high creativity, ingeniousness and unfettered imagination from the participants, so that the number of generated ideas can be as high as possible.

During the session, the ideas brought forward by its participants should not be criticized, no matter how crazy, innovative or outlandish. The session may be extended with incubation time depending on problem complexity. In accordance with known phases of creative thinking, this is a phase when we already know the problem and are interested in some overheard preliminary ideas, but we haven't yet reached the solution which would be satisfactory for us. The group selects the most interesting solution and also the one which would be most beneficial for interested parties, in the course of discussion encompassing all the proposed ideas.

Due to its simplicity and versatility brainstorming is often used, both in its classical form and in derivative versions which include: Gallery Method, 635 Method, Trigger Method, Pin-cards

Wolnowska A.E., Kasyk L.., Study on the Development of Transversal Competences of Students of Logistic [in:] Adamczak M. et al., Digitalization of Supply Chains, Spatium, Radom 2019, p. 160-176.

https://doi.org/10.17270/B.M.978-83-66017-86-3.12 
technique, Wildest idea method, Successive Integration Of Problem Elements (SIL) method, Brainwriting technique, Nominal Group Technique and others.

Another tested method was „Metaplan” which is also called a placard technique and which belongs to such a group of problem-solving methods where a graphic form is used for recording the arguments used in discussion. The form used is systematic and resembles a placard where issues are divided by aspects: how things are, how should they be, why it isn't as it should be and conclusions. This method, even though it is not really often referred to in literature, is still frequently applied in various economic branches such as construction industry, information technology, education at all levels and in all fields [Campagna 2016]. It is possible to use Metaplan for individual analysis, but the most typical application is to use a group of maybe up to a dozen or so people. The time given to the team is usually limited by the moderator or leader who does not take part in the discussion and the development of the placard.

Teamwork is dynamic and teaches concentration, quick analysis, systematizing the existing knowledge and also the knowledge streams supplied continuously by other participants. It allows for developing communication and negotiation skills, creativity, and communicativeness by stimulating the linguistic competences [Ovchinnikova et al. 2015], expressing personal opinions, conducting the discussion and working in a team.

The last method used was „Drama”, also known as „Pedagogical Drama”. It consists in one or more persons playing the roles given to them by the moderator. It is conducted in three phases:

- The leader outlines the initial situation,

- The participants prepare to play the roles assigned to them,

- The roles are played,

- The executed performance is discussed.

Similarly as with other methods, Drama can be applied for solving various problems which may be more or less complex and interdisciplinary [Kalidas 2014, Toivanen et al. 2011]. The difference here is that each of participants plays his/her role individually, which boosts their activity. This method is good for developing spontaneity, imagination and at the same time quick reactions in decision-making on the basis of own knowledge and immediate analysis of evolving situation in which the participant is immersed [Kemeh 2015]. It allows for expanding one's limits [Lehtonen et al. 2016] and capabilities in life, within the professional and social environment that

Wolnowska A.E., Kasyk L.., Study on the Development of Transversal Competences of Students of Logistic [in:] Adamczak M. et al., Digitalization of Supply Chains, Spatium, Radom 2019, p. 160-176. https://doi.org/10.17270/B.M.978-83-66017-86-3.12 
one faces, and also facilitates the perception of limitations, perspectives and consequences of decisions made by one. It constitutes a challenge for both learners and teachers at various education levels [Muszyńska et al. 2017].

\section{DATA ANALYSIS AND DISCUSSIONS}

The research into effectiveness and justification for the use of the three selected heuristic methods as means to raise the level of transversal competences have been carried out at the Maritime University in Szczecin in the period from October 2018 to the end of January 2019.

The students participating in the research were enrolled in full-time and part-time modes of study at the Logistics specialization on the Faculty of Transport Engineering and Economics. Detailed data concerning the respondents is included in Table 1.

Table 1. Information concerning responds (LP - Logistyka Przedsiębiorstw (Logistics of Enterprises), LM - Logistyka Metropolitalna (Municipal Logistics), LiZwEST - Logistyka i Zarządzanie w Europejskim Systemie Transportowym) (Logistics

\begin{tabular}{llllllll} 
& & & & \multicolumn{2}{c}{ and Management in European Transport System). } \\
\hline Direction & Specialization & $\begin{array}{l}\text { Level of } \\
\text { study }\end{array}$ & Mode of study & $\begin{array}{l}\text { Year of } \\
\text { study }\end{array}$ & $\begin{array}{l}\text { Research } \\
\text { period }\end{array}$ & $\begin{array}{l}\text { No. of students/ } \\
\text { no. of respondents }\end{array}$ & $\begin{array}{l}\text { Subject used for } \\
\text { research tests }\end{array}$ \\
\hline Logistics & - LP & I level & Full-time & III & $10.2018-$ & $\begin{array}{l}100 / 82 \text { people } \\
\text { Erasmus } 4 \text { people }\end{array}$ & $\begin{array}{l}\text { Quality } \\
\text { normalisation and } \\
\text { management in }\end{array}$ \\
& - LM & & & & 01.2019 & & logistics \\
- LiZwEST & & & & & & & \\
Logistics & & I level & Part-time & II & $10.2018-$ & $39 / 37$ people & $\begin{array}{l}\text { Quality } \\
\text { normalisation and } \\
\text { management in } \\
\text { logistics }\end{array}$ \\
\hline
\end{tabular}

Source: own elaboration.

The purpose, the methodology of research and its schedule were explained to the students with regard to their various modes of study. Each test was preceded by a theoretical and methodical introduction to maintain clarity and good comprehension of the method by respondents. The tests were carried out during lectures and exercises.

With the full-time students the brainstorming and Metaplan exercises were performed in the same six 12-persons teams and one 10-persons team. In case of part time students three 12person teams were formed. The test subjects used were related to the field of education and specialisation, e.g.

- Increasing the percentage of persons using the municipal transport means of in the city Szczecin,

Wolnowska A.E., Kasyk L.., Study on the Development of Transversal Competences of Students of Logistic [in:] Adamczak M. et al., Digitalization of Supply Chains, Spatium, Radom 2019, p. 160-176.

https://doi.org/10.17270/B.M.978-83-66017-86-3.12 
- Reducing the traffic congestion in the streets Cukrowa and Przestrzenna in the direction of Przecław,

- Expansion of the range of quality management methods and tools used by small and medium-size enterprises.

A different procedure was used in case of Pedagogical Drama, where the full-time students role-played the situations occurring during an internal audit of a quality management system following the requirements of ISO 9001:2015 standard. The part-time students on the other hand played the roles of owners of transport, forwarding and logistical processes (TSL).

During brainstorming session each of the groups selected a moderator, who performed a preliminary assessment of each student's work after the performed session. The teacher leading the tests would assess the involvement of each student after a given session was finished, summarised and its effects evaluated. The students would assess their own improvement in terms of particular competences using a questionnaire.

When Metaplan was used as a template for an exercise, each group would select a leader, a secretary and a reporter. The leader would perform the final assessment of particular students taking into account their self-assessment. Similarly as before, the students would fill in a related questionnaire and this way assess their own improvement in tested competences.

The analysis of the results of executed tests, carried out by means of a change dynamics questionnaire referring to the assessment of possessed transversal competences, provided for a finding that improvement took place for each of the competences i.e. entrepreneurship $(\mathrm{E})$, creativity $(\mathrm{Cr})$, teamwork (T) and communicativeness (Co). The levels and the distribution of competences for all the respondents, as well as by modes of study (full-time and part-time) are similar. The results are presented in detail in Figure 2.

Wolnowska A.E., Kasyk L.., Study on the Development of Transversal Competences of Students of Logistic [in:] Adamczak M. et al., Digitalization of Supply Chains, Spatium, Radom 2019, p. 160-176.

https://doi.org/10.17270/B.M.978-83-66017-86-3.12 


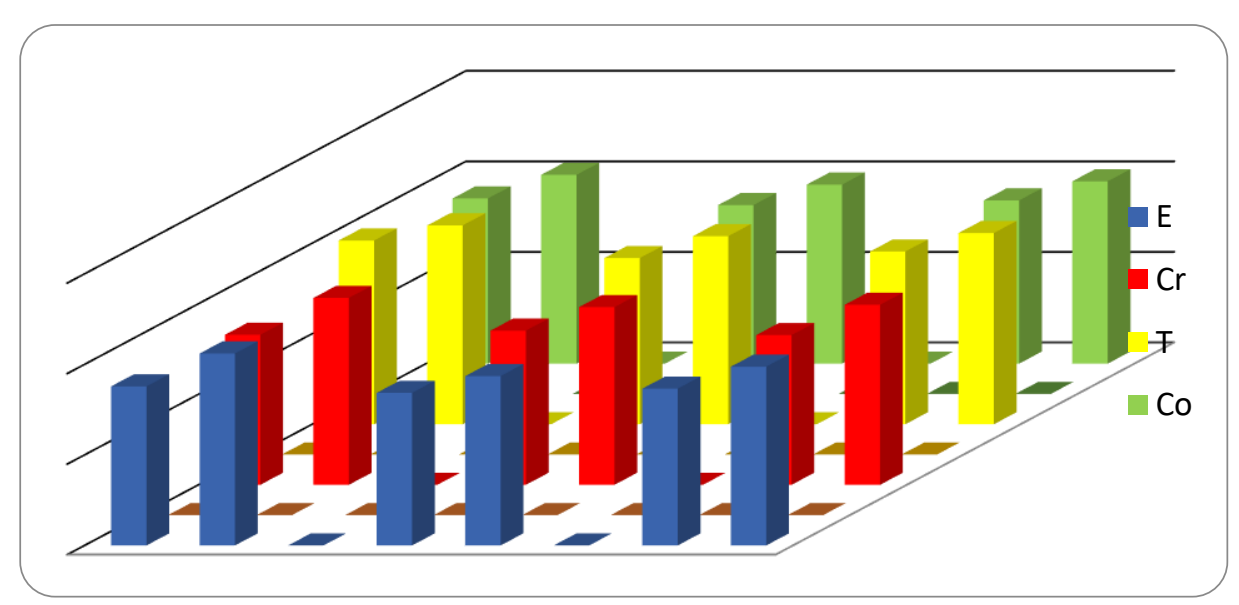

Fig. 2. Changes of competence levels for all students.

Source: own elaboration.

It can be seen that the part-time students assessed their competences higher than full-time students. However, only the difference in competence E rise is significant statistically, which is shown in bar graph in Figure 3. This is also confirmed by a t test: the value of test statistics amounted to (-3.122), which translated to probability value $\mathrm{p}=0.023$.

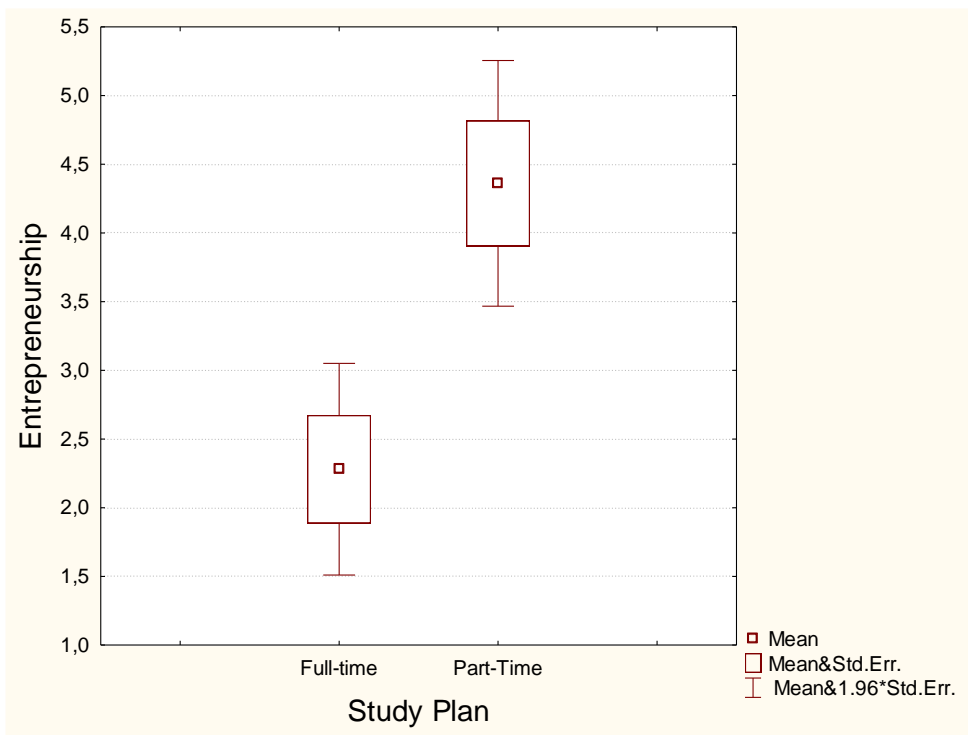

Fig. 3. Rise in E competence (entrepreneurship) for full-time and part-time students.

Source: own elaboration.

In spite of a general rise of competences among students, many of them ( $13 \%$ ) indicated a lower level of competence at the end of study in comparison with its beginning. This means that

Wolnowska A.E., Kasyk L.., Study on the Development of Transversal Competences of Students of Logistic [in:] Adamczak M. et al., Digitalization of Supply Chains, Spatium, Radom 2019, p. 160-176. https://doi.org/10.17270/B.M.978-83-66017-86-3.12 
the awareness of students about the level of own competences has risen as well, which applies in particular to full-time students whose percentage amounted to $15 \%$.

The statistical tests did not show significant differences in the results achieved by males and females, while females had higher results more often, which is illustrated in Figure 4.
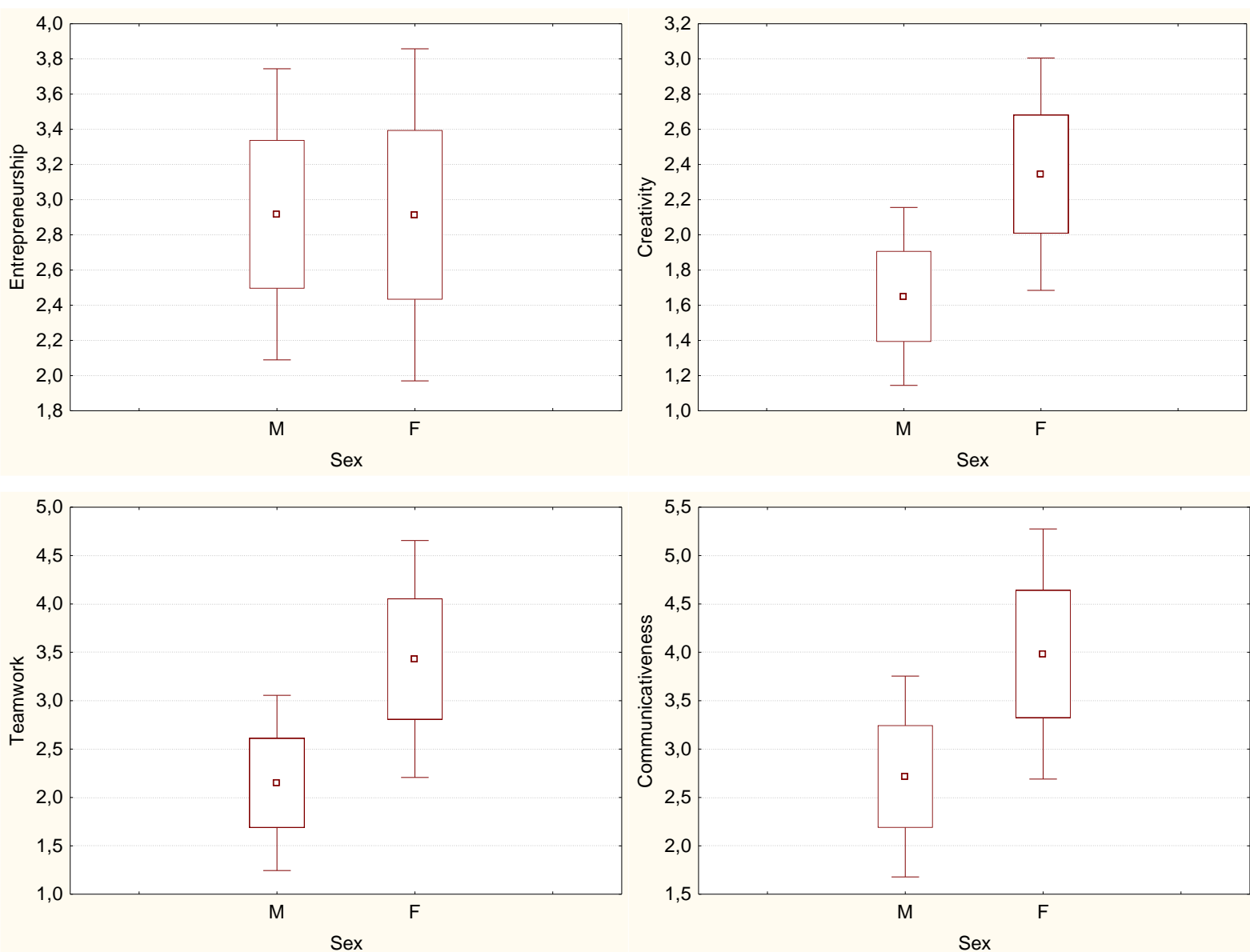

Fig. 4. Rise in competences depending on gender.

Source: own elaboration.

For full-time students the results attained by students of different specializations have been compared using a single-factor variance analysis ANOVA. The assumptions necessary for this analysis have been checked, i.e. the normality of result distributions for particular specializations as well as variance uniformity which has been verified using Lavene test (statistics $\mathrm{F}=1.02$, $\mathrm{p}=0.36)$.

Wolnowska A.E., Kasyk L.., Study on the Development of Transversal Competences of Students of Logistic [in:] Adamczak M. et al., Digitalization of Supply Chains, Spatium, Radom 2019, p. 160-176.

https://doi.org/10.17270/B.M.978-83-66017-86-3.12 
No grounds have been found to reject the posed statistical hypothesis stating that the average rise in competences is uniform for all specializations. The results of variance analysis are shown in Table 2.

Table 2 . The results of variance analysis

\begin{tabular}{|c|c|c|c|c|c|c|c|}
\hline $\begin{array}{c}\text { Sum of } \\
\text { Squares - } \\
\text { Treatment }\end{array}$ & $\begin{array}{l}\text { Degrees of } \\
\text { Freedom- } \\
\text { Treatment }\end{array}$ & $\begin{array}{l}\text { Mean Square } \\
\text { - Treatment }\end{array}$ & $\begin{array}{c}\text { Sum of } \\
\text { Squares - } \\
\text { Error }\end{array}$ & $\begin{array}{l}\text { Degrees of } \\
\text { Freedom - } \\
\text { Error }\end{array}$ & $\begin{array}{c}\text { Mean Square } \\
\text { - Error }\end{array}$ & F-value & p - value \\
\hline 96.46 & 2 & 48.23 & 11069.49 & 79 & 140.12 & 0.34 & 0.71 \\
\hline
\end{tabular}

The graph below shows some differentiation in results, however it is not significant statistically, see Figure 5.

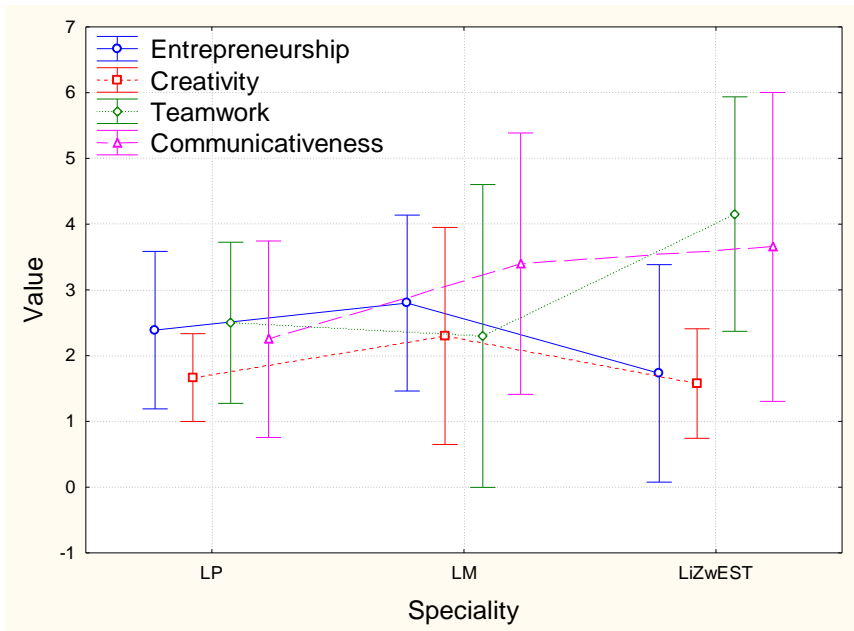

Fig. 5. Graph of averages and confidences intervals for the results in particular specialisations.

Source: own elaboration.

The following analysis refers to the rise of competences achieved by particular methods. The application of single-factor analysis did not show any significant influence of particular methods on the competence level rise. It is worth noting that the results attained by the Metaplan method were the highest for all the competences while the brainstorming method turned out to be the least effective one, see Figure 6.

Wolnowska A.E., Kasyk L.., Study on the Development of Transversal Competences of Students of Logistic [in:] Adamczak M. et al., Digitalization of Supply Chains, Spatium, Radom 2019, p. 160-176. https://doi.org/10.17270/B.M.978-83-66017-86-3.12 


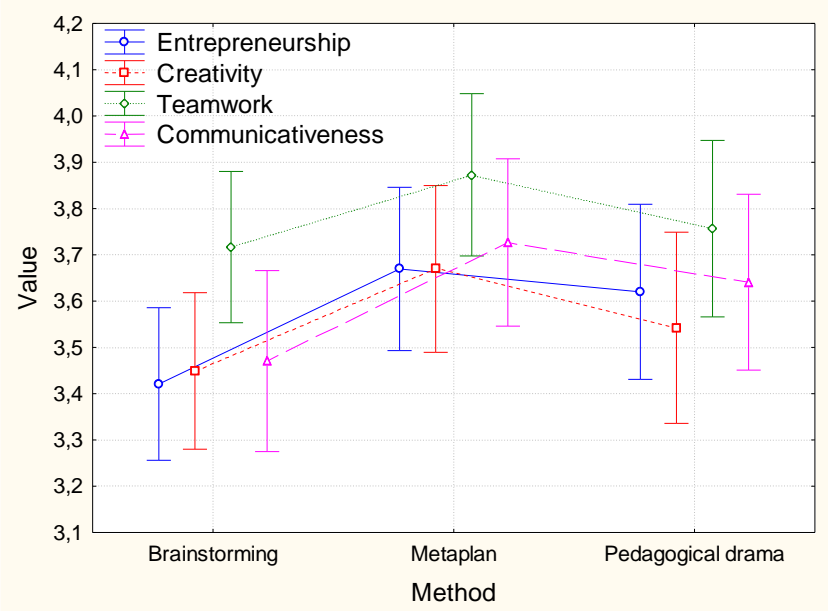

Fig. 6. Comparison of the results achieved in average competence rise for particular methods. Source: own elaboration.

No significant differences could be found in the competence rise values achieved by particular methods while taking into account modes of study, see Figure 7.
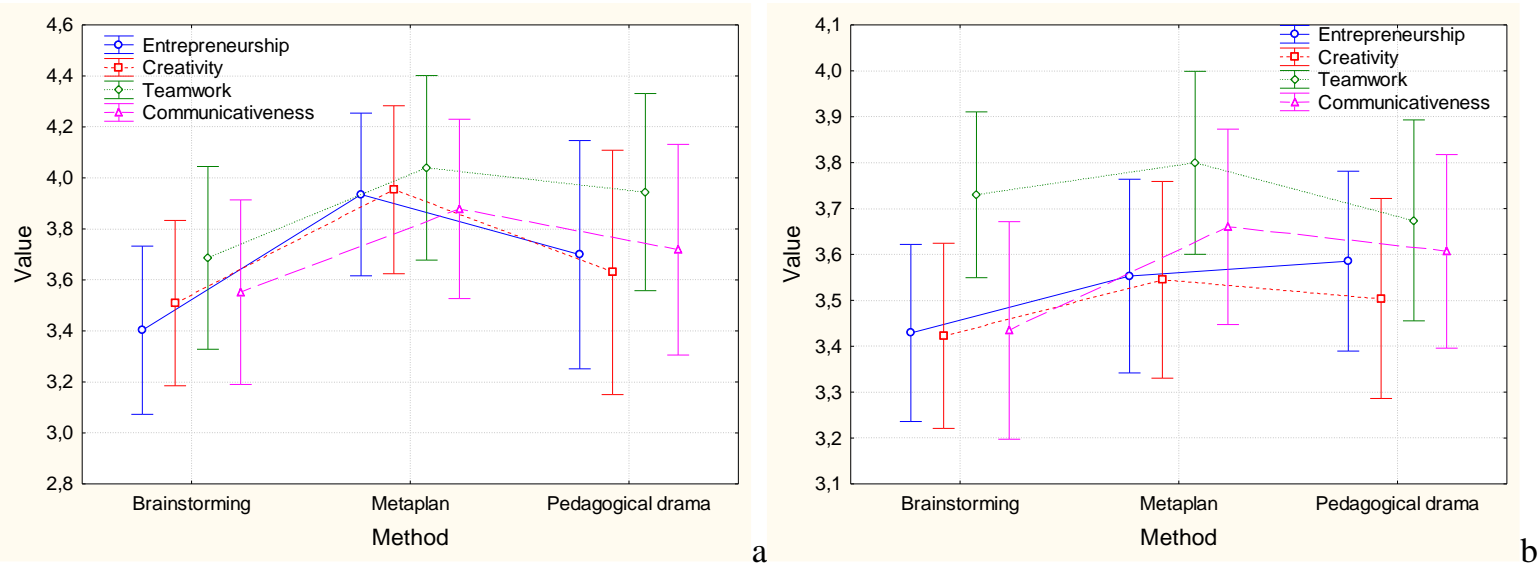

Fig. 7. A comparison of competence rise values achieved by particular methods a- part-time studies, $b$ - full-time studies. Source: own elaboration.

The most interesting comparisons of methods as used for particular competences (taking specific skills into account) are presented in the form of radar plots. For part-time studies the rises in particular skills after the application of tested methods were uniform for most of competences. Only in case of Creativity the differences in skill rises became apparent, with the capability to use the creative thinking techniques rising proportionally less for Drama, Figure 8.

Wolnowska A.E., Kasyk L.., Study on the Development of Transversal Competences of Students of Logistic [in:] Adamczak M. et al., Digitalization of Supply Chains, Spatium, Radom 2019, p. 160-176. https://doi.org/10.17270/B.M.978-83-66017-86-3.12 


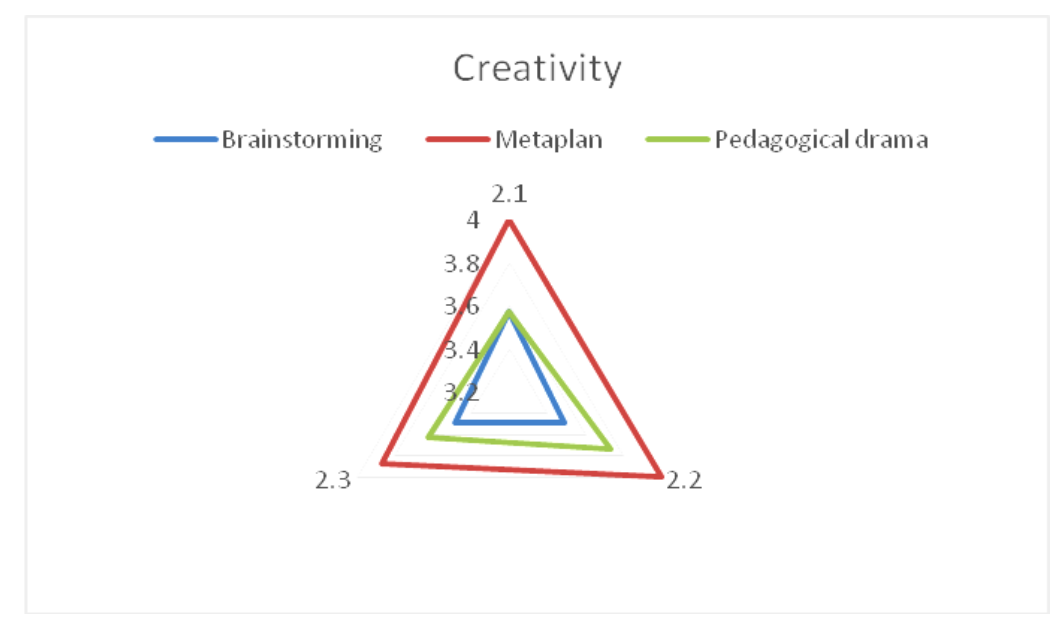

Fig 8. Creativity rise divided by particular skills, for part-time studies.

Source: own elaboration.

In case of full-time studies disproportional rises have been noted for all competences. For entrepreneurship improved by means of brainstorming the skill 1.2 noted a disproportionately low rise (the ability to notice and critically evaluate the opportunities for enterprising endeavors). For creativity improved by means of Metaplan method there was a disproportionately low rise of skill 2.2 (the ability to create original and useful solutions of problems). In case of teamwork competence, the skills would rise differently for practically each of the methods. In case of communicativeness however, the skill 4.8 (the ability to perform in public and present the self) rose disproportionately little when trained using brainstorming method, Figure 9.

Wolnowska A.E., Kasyk L.., Study on the Development of Transversal Competences of Students of Logistic [in:] Adamczak M. et al., Digitalization of Supply Chains, Spatium, Radom 2019, p. 160-176. https://doi.org/10.17270/B.M.978-83-66017-86-3.12 

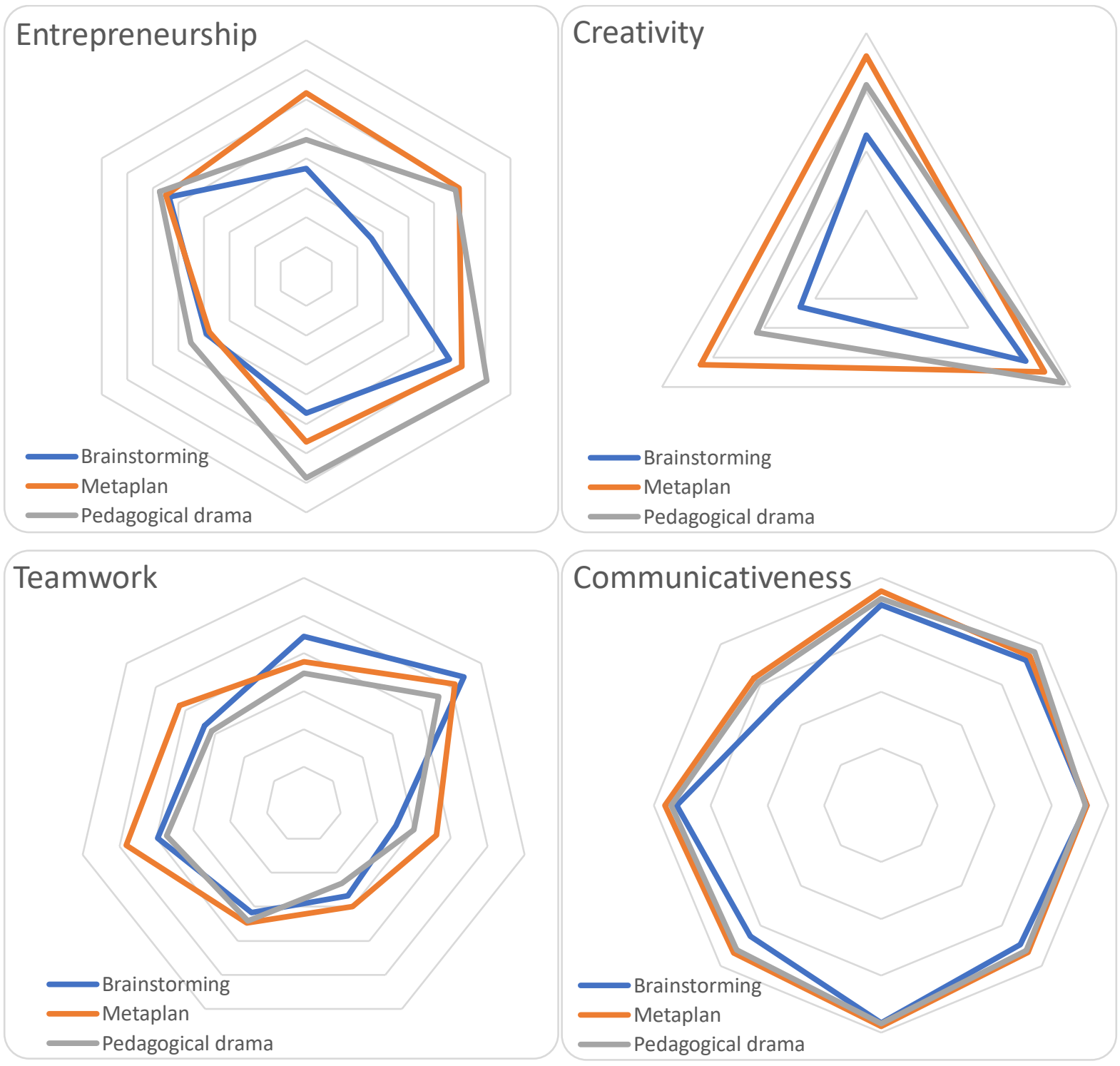

Fig. 9 Competence rises divided by particular skills, for full-time studies.

Source: own elaboration.

\section{CONCLUSION AND RECOMMENDATIONS}

In each case, the levels of proposed competences did rise among logistics students as a result of applying the proposed methods, same as their awareness and familiarity with their transversal competences (negative difference between the declared and final skill level). In spite of complexity immanent to such a research, the method as applied turned out to be effective in increasing the levels of transversal competences among logistics students. No significant

Wolnowska A.E., Kasyk L.., Study on the Development of Transversal Competences of Students of Logistic [in:] Adamczak M. et al., Digitalization of Supply Chains, Spatium, Radom 2019, p. 160-176. https://doi.org/10.17270/B.M.978-83-66017-86-3.12 
statistical differences could be discerned between the particular training methods, however the highest rise of competences was achieved using Metaplan.

No significant differences in the competence rise rate were observed among particular specializations. while the lowest rise of competences was noted among the full-time students of LP specialization. A similar story was seen when comparing the development of skills between the two sexes. even though women do in most cases develop their transversal skills better than men disregarding the mode of study. Anyway, the statistical tests did not show significant differences in this regard. When the mode of study is taken into account, a higher rise of competences can be observed among the part-time students of Logistics, which particularly applies to entrepreneurship. This may be a sign of their higher maturity and professional experience.

The research results obtained basing on the selected specializations and study mode do not prefer any particular method with regard to its effectiveness in scope of transverse skill development. The continuation of research on other study directions is thus recommended.

\section{ACKNOWLEDGEMENTS}

This article is a result of the research carried out in the Transport Engineering Institute of the Faculty of Economics and Transport Engineering of the Maritime University of Szczecin and was written within the statutory cooperation 5/S/IIT/17 on: Forming the quality in service and product manufacturing economic systems. The proposals for methodology and implementation.

\section{REFERENCES}

Amstrong M., 2002, Zarządzanie zasobami ludzkimi [A Handbook of Human Resource Management Practice], Oficyna Ekonomiczna, Kraków.

Błaszczyk A., 2019 Znaczenie edukacji w zakresie przedsiębiorczości. Przedsiębiorczość Edukacja [Entrepreneurship - Education], 15(1), 19-33, DOI: 10.24917/20833296.151.2. Campagna M., 2016, Metaplanning: About designing the Geodesign process, Landscape and Urban Planning 156, 118-128.

Wolnowska A.E., Kasyk L.., Study on the Development of Transversal Competences of Students of Logistic [in:] Adamczak M. et al., Digitalization of Supply Chains, Spatium, Radom 2019, p. 160-176. https://doi.org/10.17270/B.M.978-83-66017-86-3.12 
Defined in accordance with the recommendation of the European Parliament and of the Council of 18 December 2006 on key competences for lifelong learning (2006/962/EC) http://eurlex.europa.eu/legalcontent/EN/TXT/HTML/?uri=URISERV:c11090\&from=CS

Defined on the basis of the term creativity as set out in http://eur-lex.europa.eu/legalcontent/EN/TXT/PDF/?uri=CELEX:32008D1350\&qid=1445885985313\&from=EN

Goliński M., Graczyk-Kucharska M., Spychała M., Szafrański M., 2017, Doskonalenie kodu kompetencji zawodowych w przedsiębiorstwach - case study [Improving the Vocational Competences Code in Companies - A case stusy] Przeglad organizacji, 3, 54 - 59.

Graczyk-Kucharska, M., Szafrański, M., Goliński, M., Spychała, M., 2018, The acceleration method of development of transversal competences in the students' practical training, Cooperation of universities and employers for quality and relevance of education, (ed.) E.V. Viktorova, Publishing House of Saint-Petersburg State University of Economics, 2947.

Graczyk-Kucharska, M., Goliński, M., Szafrański M., Spychała, M., Wyrwicka, M., 2019a, Determinanty akceleracji nabywania kompetencji przekrojowych przez studentów [Determinants of Acceleration of Development Transversal Competences by the Students], Zeszyty Naukowe Politechniki Poznańskiej. Organizacja i Zarządzanie, 79, 81-99. DOI: 10.21008/j.0239-9415.2019.079.06

Graczyk-Kucharska, M., Özmen, A., Szafrański, M., Weber G.W., G.W., Golińśki, M., Spychała, M., 2019b, Knowledge accelerator by transversal competences and multivariate adaptive regression splines, Central European Journal of Operations Research, 1-25 DOI https://doi.org/10.1007/s10100-019-00636-x Publisher Name Springer Berlin Heidelberg Print ISSN 1435-246X

Kalidas C. S., 2014, Drama: A Tool for Learning, Procedia - Social and Behavioral Sciences 123, 444 - 449, DOI: 10.1016/j.sbspro.2014.01.1443.

Kemeh, M, 2015, Using solo drama to make the teaching of social studies engaging for students, INTE 2014 Procedia - Social and Behavioral Sciences 174, 2245 - 2252 doi: 10.1016/j.sbspro.2015.01.882

Wolnowska A.E., Kasyk L.., Study on the Development of Transversal Competences of Students of Logistic [in:] Adamczak M. et al., Digitalization of Supply Chains, Spatium, Radom 2019, p. 160-176. https://doi.org/10.17270/B.M.978-83-66017-86-3.12 
Lehtonen, A., Kaasinen, M., Karjalainen-Väkevä, M., Toivanen T., 2016 Promoting creativity in teaching drama, Future Academy®'s Multidisciplinary Conference Procedia - Social and Behavioral Sciences 217, 558 - 566, DOI: 10.1016/j.sbspro.2016.02.046

Muszyńska, A., Gałązka A., Urpí, C., 2017, Teacher Education through Drama. CLIL Practice in the Spanish Context, Estudios sobre Educación, 32, 179-195), doi10.15581/004.32.179195

Ovchinnikova O. M., Frantsuzskaya E. O., Lutoshkina O. S., 2015, Metaplan-based Development of Speaking Skills. The XXVI Annual International Academic Conference, Language And Culture, 27-30 October 2015. Procedia - Social and Behavioral Sciences 200 ( 2015 ) 624 - 630, DOI:10.1016/j.sbspro.2015.08.049.

Sawyer, R. K., 2006, Educating for innovation, Thinking Skills and Creativity 1, 41-48, DOI:10.1016/j.tsc.2005.08.001.

Spychała M., 2014, Analysis and Improvement of the Process Engineers Levels of Competence in a Manufacturing Company, [in:] P. Golińska (ed.), Logistic Operations, Supply Chain Management and Sustainability, Springer, 395-409.

Spychała M., Matejun M., 2015, Badanie ocen wybranych kompetencji menedżerskich studentów WOiZ Politechniki Łódzkiej, Marketing i Rynek 5, 1274-1293.

Spychała M., Szafrański M., Graczyk-Kucharska M., Goliński M., 2017, The Method of Designing Reference Models of Workstations. In: Proceedings of the 18th European Conference on Knowledge Management. Limited, International University of Catalonia, Barcelona, 930-939.

Srikanthan G., Dalrymple J., 2004, A synthesis of a quality management model for education in universities. International Journal of Educational Management, 18(4):266-279, DOI: $10.1108 / 09513540410538859$.

Sutherland J., Canwell D., 2007, Klucz do zarządzania zasobami ludzkimi. Najważniejsze teorie, pojęcia, postaci [Key Concepts in Human Resource Management], Wydawnictwo Naukowe PWN, Warszawa.

Szafranski M., Golinski M., Simi H. (eds.), 2017, The acceleration of development of transversal competences. Centria University of Applied Sciences, Kokkola 
Szafrański M., 2015, Acceleration of educating as an external factor supporting preventive and improving actions in businesses. In: Ahram T., Karwowski W., Schmorrow D. (eds) Procedia manufacturing, 6th international conference on applied human factors and ergonomics and the affiliated conferences, AHFE 2015, vol 3, pp 4948-4955

Szaniawska D., Wolnowska A., 2015, Moduł doskonalenia jakości procesów dla kierunków kształcenia inżynieria Produkcji i Logistyka [Process quality improvement module for Production Engineering and Logistics study Fields], 2, 73-83. ISSN 2084-1469

Toivanen, T., Komulainen, K., Ruismäki, H., 2011, Drama education and improvisation as a resource of teacher student's Creativity, International Conference on Education and Educational Psychology (ICEEPSY 2010), Procedia Social and Behavioral Sciences 12, 60-69, DOI:10.1016/j.sbspro.2011.02.010.

Zioło, Z., Rachwał, T., 2019, Zarys uwarunkowań dalszego rozwoju przedsiębiorczości w układach przestrzennych. Przedsiębiorczość - Edukacja [Entrepreneurship - Education], 15(1), 7-18. DOI: 10.24917/20833296.151.1.

Wolnowska A.E., Kasyk L.., Study on the Development of Transversal Competences of Students of Logistic [in:] Adamczak M. et al., Digitalization of Supply Chains, Spatium, Radom 2019, p. 160-176. https://doi.org/10.17270/B.M.978-83-66017-86-3.12 